\title{
Protein supplementation of stocker cattle in the Northern Great Plains
}

\author{
ELAINE E. GRINGS, DON C. ADAMS, AND ROBERT E. SHORT
}

\begin{abstract}
Authors are animal scientist, USDA-ARS, Ft. Keogh Livestock and Range Research Laboratory, Rt. I Box 2021, Miles City, Mont. 59301; animal scientist, University of Nebraska-Lincoln West Central Research and Extension Center, Rt. 4 Box 46A, North Platte 69101; and animal physiologist, USDA-ARS, Ft. Keogh Livestock and Range Research Laboratory. At the time of the research Don Adams was animal scientist, USDA-ARS, Ft. Keogh Livestock and Range Research Laboratory.
\end{abstract}

\section{Abstract}

A comparison of the response of varying classes of growing beef cattle to protein supplementation was conducted on Northern Great Plains rangeland during the summer and early fall. Response was evaluated in 2 experiments, conducted in 1988 and 1989, by measuring organic matter intake and body weight gain in 13-month-old (spring-born steers) and 7-month-old steers (fall-born steers), which received either a $26 \%$ crude protein supplement or no supplement. Weight gain was also monitored in 7month old heifers (fall-born heifers). In experiment 1, springborn steers were fed $1.28 \mathrm{~kg}$ and fall-born steers and heifers 1.64 $\mathrm{kg}$ of protein supplement every other day. During experiment 2, spring-born steers were fed supplement at a rate of $1 \mathrm{~kg}$ and fallborn steers and heifers at $1.8 \mathrm{~kg}$ every other day. Intake of forage organic matter for steers was not affected $(P>0.10)$ by supplementation in either experiment. In experiment 1 , total organic matter intake tended to be increased by protein supplementation in June but not in August (date $x$ supplementation level interaction, $P=0.08)$. Forage organic matter digestibility was greater $(P$ $<0.01$ ) in June than in August during experiment 1 and in August than September in experiment 2. In experiment 1, this difference was greater for fall-born steers than spring-born steers. In experiment 1 , supplementation increased $(P<0.01)$ average daily gain of cattle from 0.63 to $0.78 \mathrm{~kg} /$ day. In experiment 2, daily gain of cattle was increased $(P<0.01)$ from 0.62 to $0.82 \mathrm{~kg} /$ day with protein supplementation. Also, in experiment 2 , cattle receiving supplement were $18 \mathrm{~kg}$ heavier $(P<0.05)$ at the end of the grazing season than unsupplemented controls. Protein supplementation increased weight gains of growing cattle in the late summer in the Northern Great Plains. The advantage was most consistent for fall-born steers with higher relative protein requirements.

Key Words: forage quality, intake, rangeland, supplements

Past research has shown that range forage in eastern Montana may become deficient in protein for growing cattle during late summer

\footnotetext{
This paper is a contribution from the USDA-ARS and the Montana Agricultura Experiment Station. Publication has been approved by the director of the Montana Agr. Exp. Joumal Ser. J-2826.

Mention of a trade name or a specific proprietary product does not constitute a guarantee or warranty by the authors or USDA-ARS nor does it imply the approval of these products to the exclusion of others.

Manuscript accepted 17 Jan. 1994.
}

(Adams and Short 1988). Unsupplemented steers grazing native range in late August and early September have been shown to cease gaining or even to lose weight (Currie et al. 1989). Protein supplementation may alleviate this depression in weight gain by supplying a limiting nutrient. In addition, protein supplementation may improve nutrient intake and utilization through an increase in forage intake and digestibility (Caton et al 1988; DelCurto 1990a,b; Sanson et al. 1990). However, the effect of protein supplementation on forage intake is not consistent (Kartchner 1980). Protein requirements for growth differ by sex and body weight (NRC 1984). As cattle grow, protein requirements, per unit of body weight and per unit of gain, decrease. In addition, heifers require less protein at high rates of gain than steers. Due to differences in requirements and growth rates, response to supplemental protein may vary with age and sex of grazing cattle. The objectives of this study were to evaluate the effects of protein supplementation on intake and weight gain of cattle in different stages of growth, grazing Northern Great Plains rangelands.

\section{Materials and Methods}

Experiments were conducted in a single 176 ha pasture of native range at the Fort Keogh Livestock and Range Research Laboratory, Miles City, Mont. $\left(46^{\circ} 22^{\prime} \mathrm{N} 105^{\circ} 5^{\prime} \mathrm{W}\right)$. Dominant forages were western wheatgrass (Pascopyrum smithii, [Rydb.] Love); Japanese brome (Bromus japonicus Thunb.), blue grama (Bouteloua gracilis, [H.B.K.] Lag. ex. Griffiths) and needle-and-thread (Stipa comata, Trin. and Rupr.). Precipitation was $134 \mathrm{~mm}$ in 1988 and $383 \mathrm{~mm}$ in 1989 compared to a 92-year average of $338 \mathrm{~mm}$ (Fig. 1).

In the first study (1988), the pasture was stocked with twenty-four 13-month-old steers (spring-born steers), eleven 7-month-old fallborn steers and 13 fall-born heifers. Protein supplementation was provided to 13 spring-born steers and 12 fall-born calves (6 steers, 6 heifers) at rates of 1.28 and $1.64 \mathrm{~kg}$ of supplement (335 and $429 \mathrm{~g}$ crude protein) every other day, respectively. Supplementation was by group feeding of each animal type. This level of supplement was expected to meet the needs of cattle (NRC 1984) gaining about 0.8 to $1.0 \mathrm{~kg} / \mathrm{day}$, assuming a daily dry matter intake of $2 \%$ of body weight of a forage containing 6 to $6.5 \%$ crude protein (Adams et al. 1987; Ward et al. 1990a). In study 2 (1989), the same pasture was stocked with 24 spring-born steers (12 control, 12 supplemented), 24 fallborn steers ( 12 control, 12 supplemented) and 11 fall-born heifers (6 control, 5 supplemented). Spring-born steers were fed $1.0 \mathrm{~kg}$ ( $274 \mathrm{~g}$ crude protein) and fall-born calves $1.8 \mathrm{~kg}$ ( $493 \mathrm{~g}$ crude protein) of the supplement every other day. Differences in the amount of supplement fed in the 2 years were because of different initial weights of cattle. Cattle were group fed by animal type, except during the fecal 


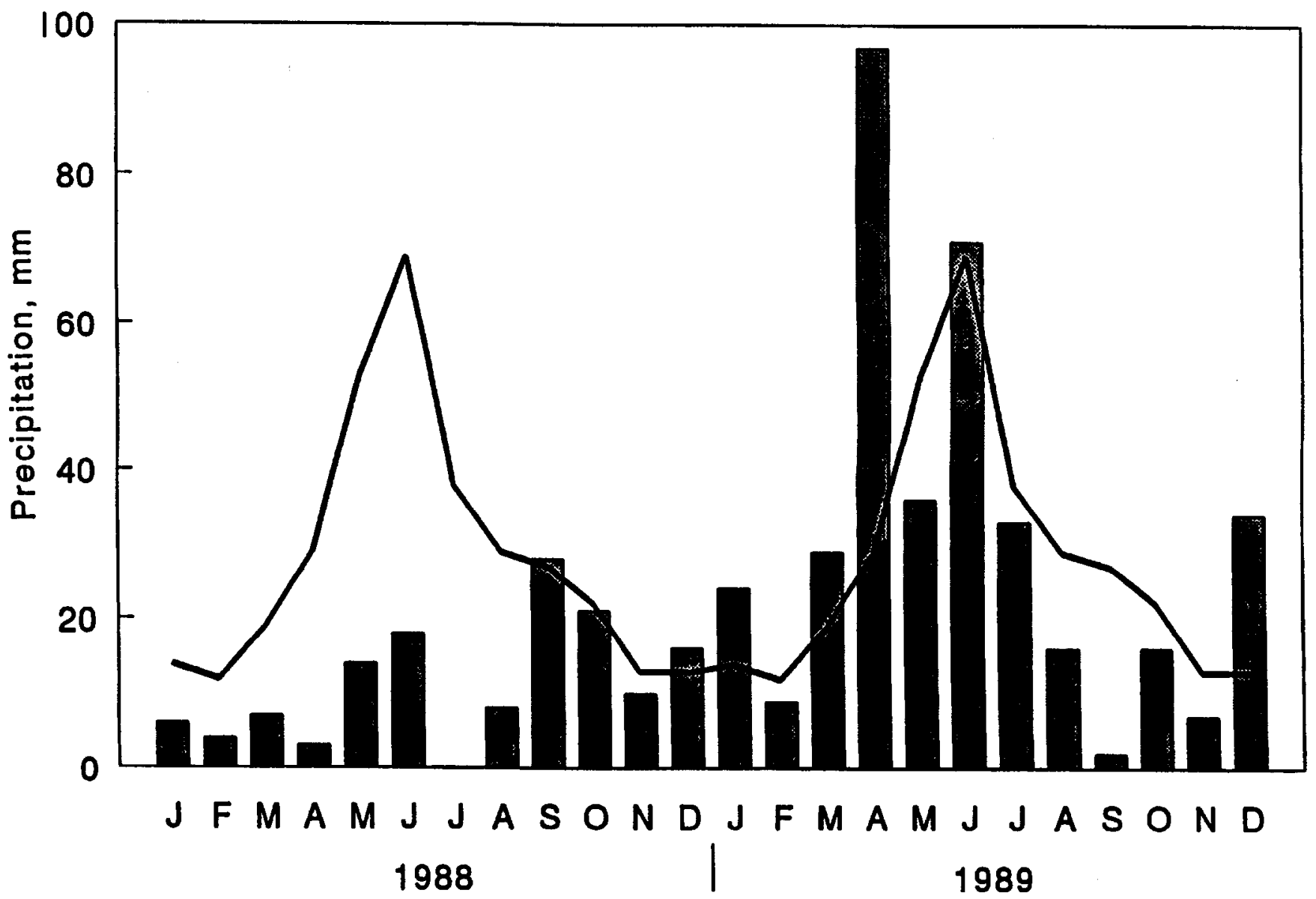

Fig. 1. Monthly precipitation during the 2 years the studies were conducted (1988 and 1989). Bars represent actual precipitation while the line represents a 92-year average.

collection period, when cattle were individually fed. The supplemental protein was provided as a pelleted $50 \%$ soybean meal, $25 \%$ barley, $25 \%$ wheat cake. Chemical composition of the supplement is shown in Table 1. Animals were allowed access to minerals and water at all times.

Preweaning weight gains of fall-born calves were $0.76 \mathrm{~kg} /$ day in 1988 and $0.62 \mathrm{~kg} /$ day in 1989 . Winter weight gain of spring-born cattle in 1989 averaged $0.77 \mathrm{~kg} /$ day. One-half of the spring-born cattle used in 1987 were purchased prior to the study and previous winter weight gain was unknown for these animals.

Forage intakes were estimated for steers only. In experiment 1, 10 fall- and 10 spring-born steers were fitted with fecal collection bags during 5-day periods in June (20 - 24 June) and August (15 - 19 August). Fecal bags were emptied each morning and a subsample collected and dried at $60^{\circ} \mathrm{C}$. A 5-day composite was then made using

Table 1. Chemical composition ( $\%$ of dry matter) of protein supplements fed to growing cattle in Experiments 1 and 2.

\begin{tabular}{|c|c|c|}
\hline Item & Experiment 1 & Experiment 2 \\
\hline & \multicolumn{2}{|c|}{$\longrightarrow(\%) \longrightarrow$} \\
\hline Organic matter & 95.3 & 87.7 \\
\hline Crude protein & 26.2 & 27.4 \\
\hline Neutral detergent fiber & 18.4 & 13.9 \\
\hline Acid detergent fiber & 7.3 & 8.0 \\
\hline Acid detergent lignin & 1.1 & 1.4 \\
\hline
\end{tabular}

$0.1 \%$ of the daily fecal dry matter. Forage organic matter indigestibility was estimated by marker ratio techniques using indigestible neutral detergent fiber (Cochran et al. 1986). In experiment 2, 24 steers were given a sustained release bolus containing chromic sesquioxide ${ }^{1}$ with a daily $\mathrm{Cr}$ release rate of $1123 \mathrm{mg}$. Rectal grab samples of feces were collected once daily over two 5-day periods ( $31 \mathrm{July}-4$ August, $11-15$ September), dried at $60^{\circ} \mathrm{C}$, and composited on an equal dry weight basis for each animal. Fecal samples from both experiments were ground to pass a 1-mm screen in a Wiley mill and analyzed for dry matter, organic matter (AOAC 1989), and indigestible neutral detergent fiber. Fecal samples from experiment 2 were also analyzed for $\mathrm{Cr}$ by atomic absorption spectrophotometry (Williams et al. 1962). Fecal organic matter output was estimated by dividing $\mathrm{Cr}$ released by the sustained release bolus by the concentration of $\mathrm{Cr}$ in the feces. Fecal output attributed to supplement was subtracted from total fecal output to estimate fecal output attributed to forage intake. For both experiments, forage organic matter intake was estimated by dividing fecal organic matter output from forage by forage organic matter indigestibility. Estimates of fecal output using the sustained release bolus have been reported to be within $10 \%$ of total fecal collections for steers on similar forage (Adams et al. 1991).

Five mature (3-4 years old) steers, fitted with esophageal cannulae, grazed with the other cattle during the week of fecal collections.

\footnotetext{
Taptec Chrome, Nufarm, Auckland, New Zealand
} 
Table 2. Chemical composition of diets consumed by esophageally-fistulated steers at the time of intake trials.

\begin{tabular}{|c|c|c|c|c|}
\hline & \multicolumn{2}{|c|}{ Experiment 1 (1988) } & \multicolumn{2}{|c|}{ Experiment 2 (1989) } \\
\hline & $21 \mathrm{Jun}$. & 21 Aug. & 1 Aug. & 13 Sep. \\
\hline & $\ldots$ & $--(\%$ of $d$ & $\ldots$ & $\ldots$ \\
\hline Organic matter & 89.8 & 89.6 & 90.7 & 88.2 \\
\hline & $-\ldots$ & (\% of org: & & \\
\hline Crude protein & 8.1 & 6.2 & 8.8 & 9.4 \\
\hline $\begin{array}{l}\text { Neutral detergent } \\
\text { fiber }\end{array}$ & 77.0 & 77.4 & 74.8 & 75.4 \\
\hline Acid detergent & & & & \\
\hline $\begin{array}{l}\text { fiber } \\
\text { Acid detergent }\end{array}$ & 49.1 & 53.9 & 51.9 & 59.0 \\
\hline lignin & 6.1 & 5.2 & 7.0 & 16.2 \\
\hline $\begin{array}{l}\text { Acid detergent } \\
\text { insoluble nitrogen }\end{array}$ & 0.29 & 0.28 & 0.36 & 0.77 \\
\hline
\end{tabular}

Esophageal collections were made once during each intake trial. Steers were penned at 1600 with water but no feed available. Collections were made the following morning at 0700 . Collection periods lasted from 20 to $30 \mathrm{~min}$. Esophageal masticate samples were oven dried at $55^{\circ} \mathrm{C}$, ground through a Wiley mill, and analyzed for dry matter, organic matter, and acid detergent fiber by AOAC (1989) procedures, acid detergent lignin and neutral detergent fiber by the procedures of Goering and Van Soest (1970), indigestible neutral detergent fiber, and crude protein (Hach 1987).

Steers were weighed on a non-shrunk basis and average daily gain was calculated as final weight minus initial weight divided by the number of days of the study. Experiment 1 was terminated after 64 days ( 9 June to 11 August) because of low forage availability associated with low precipitation (Fig. 1). Experiment 2 was conducted over an 80-day period ( 30 June to 18 September).

Data were analyzed as 2 separate experiments because sample dates and techniques for intake measurement varied between years. Intake and digestibility data were analyzed using the general linear models procedure of SAS (1989) with a model that included steer age, supplementation level, steer age $x$ supplementation level, steer within age by supplementation level, date, steer age $x$ date, supplementation level $x$ date, and steer age $x$ supplementation level $x$ date. Steer age, supplementation level and the interaction were tested using steer within age by supplementation level (16 df, experiment $1 ; 20$ df, experiment 2) as the error term. Animal growth data were analyzed with a $2 \times 3$ (supplementation level $x$ animal type) arrangement of treatments. The residual error was used to test effects. When a significant $F$ value was obtained, individual ( $1 \mathrm{df}$ ) orthogonal contrasts were used to test control vs supplemented cattle within animal type (spring-born steer, fall-born steer, and fall-born heifer).

\section{Results and Discussion}

\section{Diet Quality}

In experiment 1 , dietary crude protein concentrations (Table 2) were less than expected for the summer months for this area (Adams and Short 1988). Low precipitation (Fig. 1) during the year apparently reduced both quality and quantity of forage. In experiment 2 , diet quality appeared to be greater than in experiment 1 . Based on estimated intakes, about $80 \%$ of the NRC (1984) requirement for crude protein of steers was met through forage consumption. Addition of the protein supplement increased crude protein intake to $85 \%$ of requirement in experiment 1 and $98 \%$ of requirement in experiment 2.

\section{Intake and Digestibility}

In experiment 1 , intake of forage organic matter ( $\mathrm{g} / \mathrm{kg} \mathrm{BW}$ ) and forage organic matter digestibility $(\%)$ were not affected by supplementation, but total organic matter intake was greater $(P<0.01)$ in June for steers fed supplement than for non-supplemented controls (Table 3). Total organic matter intake was not affected by supplementation in August. Organic matter intake (forage and total) was greater $(P<0.01)$ in August than June (Table 4$)$. There was an effect of steer age $(P<0.01)$, with fall-born steers consuming more organic matter per unit body weight than spring-born steers. Digestibility of forage organic matter was greater $(P<0.01)$ in June than August, which may be associated with the higher diet quality in June. There was a greater difference in digestibility between June and August for fall-born steers than for spring-born steers (type $\mathrm{x}$ date interaction, $P$ $<0.05$ ).

In the second experiment, intakes of forage and total organic matter $(\mathrm{g} / \mathrm{kg} \mathrm{BW})$ and forage organic matter digestibility for steers were not affected $(P>0.10)$ by supplementation. Fall-born steers consumed more $(P<0.01)$ organic matter on a body weight basis than did spring-born steers and forage digestibility was $1.5 \%$ lower $(P<$ 0.05 ) in fall-born steers (Table 4). Differences $(P<0.01$ ) were observed between July and September trials for forage and total organic matter intake and organic matter digestibility. Diet digestibility averaged $19.5 \%$ less in September than in August. This may be related to the large difference in dietary acid detergent lignin

Table 3. Least squares means of organic matter $(O M)$ intake $(g / k g ~ B W)$ of steers, Experiments 1 .

\begin{tabular}{|c|c|c|c|c|c|c|c|c|c|}
\hline \multirow[b]{3}{*}{ Item } & \multicolumn{4}{|c|}{ Spring-born } & \multicolumn{4}{|c|}{ Fall-bom } & \\
\hline & \multicolumn{2}{|c|}{ Cuntrol } & \multicolumn{2}{|c|}{ Supplemented } & \multicolumn{2}{|c|}{ Control } & \multicolumn{3}{|c|}{ Supplemented } \\
\hline & Date $1^{\mathbf{a}}$ & Date 2 & Date 1 & Date 2 & Date 1 & Date 2 & Date 1 & Date 2 & SEM \\
\hline
\end{tabular}

No. of animals

a Dates for intake trials were $20-24$ Jun. and $15-19$ Aug. 1988.
bThere was a significant effect of date in the model $(P<0.01)$.

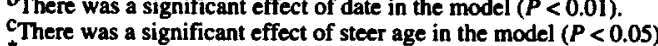

*Means comparing control and supplemented cattle within age and date differ at $P<0.05$.

$\mathrm{d}_{\text {There was a tendency toward an effect of supplementation level }(P=0.06) \text {. }}$

There was a tendency toward a date $\mathrm{x}$ supplementation level interaction $(P=0.08)$. 
Table 4. Least squares means of organic matter (OM) intake $(\mathrm{g} / \mathrm{kg} \mathrm{BW})$ and digestibility in steers, Experiments 1 and 2.

\begin{tabular}{|c|c|c|c|c|c|}
\hline \multirow[b]{2}{*}{ Item } & \multicolumn{2}{|c|}{ Spring-born } & \multicolumn{2}{|c|}{ Fall-bom. } & \multirow[b]{2}{*}{ SEM } \\
\hline & Date 1 & Date 2 & Date & Date 2 & \\
\hline Experiment 1 & \multirow{2}{*}{\multicolumn{2}{|c|}{10}} & \multirow{2}{*}{\multicolumn{2}{|c|}{10}} & \\
\hline No. of animals & & & & & \\
\hline Forage OM & & & & & \\
\hline Intake & 15.1 & 18.7 & 16.9 & 22.3 & 0.3 \\
\hline Digestibility, \% & 65.9 & $64.0^{*}$ & 66.9 & $61.7^{*}$ & 0.3 \\
\hline \multicolumn{6}{|l|}{ Experiment 2} \\
\hline No. of Animals & \multirow{2}{*}{\multicolumn{2}{|c|}{11}} & \multirow{2}{*}{\multicolumn{2}{|c|}{13}} & \\
\hline Forage OM & & & & & \\
\hline Intake $^{\text {sed }}$ & 15.6 & 14.0 & 22.8 & 19.1 & 0.4 \\
\hline Digestibility, \% & 68.7 & 50.0 & 68.0 & 48.3 & 0.3 \\
\hline Total OM intake & 16.2 & 14.6 & 24.4 & 20.5 & 0.4 \\
\hline
\end{tabular}

aDates for intake trials were $20-24$ Jun. and $15-19$ Aug. 1988 for experiment 1 and 31 Jul. - 3 Aug. and 11 - 15 Sep. 1989 for experiment 2.

There was a significant effect of date in the model $(P<0.01)$.

c,d There was a significant effect of steer age in the model at $P<0.05$ and $P<0.01$, respectively.

There was a significant steer age $x$ date interaction $(P<0.05)$.

observed between the 2 intake periods in experiment 2 . There was no difference in lignin content between dates in experiment 1 and this may partially explain the smaller differences in organic mattèr digestibility observed in experiment 1 compared to experiment 2 .

Goestch et al. (1990, 1991) has suggested that fall-born calves would have lower capacity than yearlings for consumption of lowquality forages. This was not found to be the case for steers grazing Northern Great Plains rangelands during the summer months. Across both experiments, fall-born steers consumed $39 \%$ more forage on a body weight basis than did spring-born steers. Coleman and Evans (1986) found no difference in intake on a metabolic body weight basis between fall- and spring-born calves fed alfalfa pellets. Differences in intake between animals of different age and liveweight may be dependent on forage quality.
Differences in organic matter intake over time varied between years. In experiment 1 , steers consumed more forage in the second intake trial than in the first with the opposite occurring in experiment 2. Differences between experiments may be related to the difference in timing of intake studies. In contrast, we previously observed no effect of advancing maturity of eastern Montana native range vegetation on organic matter intake in yearling steers from early May to late October (Adams et al. 1987).

Intake response to protein supplementation on rangeland has been varied. No response (Krysl et al. 1989) or positive responses have been observed (Caton, et al. 1988; DelCurto 1990a,b; Sanson et al. 1990). Differences in response have been suggested to be related to forage quality (Caton et al. 1988) and environmental conditions (Kartchner, 1980). Ward et al. (1990b) found no effect of protein supplementation on forage or total organic matter intake by steers grazing southeastern Montana rangeland in winter. In the current study, total organic matter intake was increased due to supplementation in June during experiment 1 , indicating that steers were not substituting supplement for forage at this time.

\section{Animal Performance}

Average daily gains were increased $(P<0.01)$ by protein supplementation in the first experiment. Final weights were increased by supplementation $(P<0.01)$ for fall-born steers but not for spring-born steers or fall-born heifers (Table 5).

In experiment 2, average daily gain of fall-born steers was again increased $(P<0.01)$ by protein supplementation (Table 5 ). Final weights were also increased $(\mathrm{P}<0.05)$ by supplementation. Springborn steers and fall-born steers and heifers fed supplement were 18, 20 , and $15 \mathrm{~kg}$ heavier, respectively, at the end of the grazing period than their nonsupplemented counterparts.

The decreased response of final weight to supplementation observed in the first experiment compared to the second was due to the shorter period that the cattle were fed supplement in experiment 1 ( 60 days versus 80 days in experiment 2 ). Although standing crop was not measured, cattle were removed from pastures in August of 1988 due to limited forage during severe drought.

Table 5. Least squares means for weight and average daily gains of steers and heifers in 2 years.

\begin{tabular}{|c|c|c|c|c|c|c|c|}
\hline \multirow[b]{2}{*}{ Item } & \multicolumn{2}{|c|}{ Spring-born steers } & \multicolumn{2}{|c|}{ Fall-born steers } & \multicolumn{2}{|c|}{ Fall-borm heifers } & \multirow[b]{2}{*}{ SEM } \\
\hline & Control & Supplemented & Control & Supplemented & Control & Supplemented & \\
\hline \multicolumn{8}{|l|}{ Experiment 1} \\
\hline No. of animals & 11 & 13 & 5 & 6 & 7 & 6 & \\
\hline Initial weight, kg* & 334 & 327 & 205 & 226 & 215 & 212 & 3 \\
\hline Final weight, $\mathrm{kg}^{\mathrm{acc}}$ & 376 & 380 & $237^{* *}$ & $277^{* *}$ & 261 & 259 & 3 \\
\hline $\begin{array}{l}\text { ADG, kg/dayd } \\
\text { Experiment } 2\end{array}$ & 0.66 & 0.83 & 0.50 & 0.78 & 0.72 & 0.74 & 0.02 \\
\hline No. of animals & 12 & 12 & 12 & 12 & 6 & 5 & \\
\hline Initial weight, kg & 383 & 389 & 184 & 183 & 185 & 182 & 3 \\
\hline Final weight, $\mathbf{k g}^{\mathrm{ac}}$ & 422 & 442 & 241 & 260 & 236 & 251 & 3 \\
\hline$A D G, \mathrm{~kg} / \mathrm{day}^{\mathrm{ed}}$ & 0.52 & 0.65 & 0.71 & 0.95 & 0.63 & 0.85 & 0.02 \\
\hline
\end{tabular}

There was an effect of animal type $(P<0.01)$.

bThere was an animal type $X$ supplementation level interaction $(P=0.05)$.

$c, \mathrm{~d}$ There were effects of supplementation level in the model at $P<0.05$ and $P<0.01$, respectively.

** Means within animal type differ $(P<0.01)$. 
The results of this study show that protein supplementation may be beneficial to growing cattle grazing Northern Great Plains rangelands in late summer and fall. The increase in weight gain can occur without an associated increase in forage intake. Response may be limited, however, if forage availability or quality is decreased due to drought. Younger (fall-born) cattle respond to protein supplementation more consistently than do older (previous year's spring-born) cattle. The decision to supplement should be made based upon expected response coupled with economic and management considerations.

\section{Literature Cited}

Adams, D. C., and R. E. Short. 1988. The role of animal nutrition on productivity in a range environment. pp. 37-43 In: R.S. White and R.E. Short (eds.), Achieving efficient use of rangeland resources. Mont. Agr. Exp. Sta., Bozeman, Mont.

Adams, D. C., R. C. Cochran, and P. O. Currie. 1987. Forage maturity effects on rumen fermentation, fluid flow, and intake in grazing steers. J. Range Manage. 40:404-408.

Adams, D. C., R. E. Short, M. M. Borman, and M. D. MacNeil. 1991. Estimation of fecal output with an intra-ruminal continuous release marker device. J. Range Manage. 44:204-207.

AOAC. 1989. Official methods of analysis. 15th ed. Assoc. Official Anal. Chem., Washington, DC.

Caton, J. S., A. S. Freeman, and M. L. Galyean. 1988. Influence of protein supplementation on forage intake, in situ forage disappearance, ruminal fermentation and digesta passage rates in steers grazing dormant blue grama rangeland. J. Anim. Sci. 66:2262-2271.

Cochran, R. C., D. C. Adams, J. D. Wallace, and M. L. Galyean. 1986. Predicting digestibility of different diets with internal markers: Evaluation of four potential markers. J. Anim. Sci. 63:1476-1483.

Coleman, S.W., and B.C. Evans. 1986. Effect of nutrition, age and size on compensatory growth in two breeds of steers. J. Anim. Sci. 63:1968-1982.

Currie, P. O., J. D. Volesky, D. C. Adams, and B. W. Knapp. 1989. Growth patterns of yearling steers determined from daily live weights. J. Range Manage. 42:393-396.

DelCurto, T., R. C. Cochran, L. R. Corah, A. A. Beharka, E. S. Vanzant, and D. E. Johnson. 1990a. Supplementation of dormant tallgrass-prairie forage: II. Performance and forage utilization characteristics in grazing beef cattle receiving supplements of different protein concentrations. J. Anim. Sci. 68:532-542.
DelCurto, T., R. C. Cochran, T. G. Nagaraja, L. R. Corah, A. A. Beharka, and E. S. Vanzant. 1990b. Comparison of soybean meal/sorghum grain, alfalfa and dehydrated alfalfa pellets as supplemental protein sources for beef cattle consuming dormant tallgrass-prairie forage. J. Anim. Sci. 68:2901-2915.

Goering, H. K., and P. J. VanSoest. 1970. Forage fiber analysis (apparatus, reagents, procedures, and some applications). Agr. Handbk. No. 379. ARSUSDA, Washington, DC.

Goetsch, A. L., L. A. Forster, Jr., G. E. Murphy, E. W. Grant, D. L. Galloway, Sr., and C. P. West. 1990. Digestion and live-weight gain by beef cattle consuming bermudagrass supplemented with grain or different high-protein foodstuffs. Anim. Prod. 51:263-275.

Goetsch, A. L., G. E. Murphy, E. W. Grant, L. A. Forster, Jr.,D. L. Galloway, Sr., C. P. West, and Z.B. Johnson. 1991. Effects of animal and supplement characteristics on average daily gain of grazing beef cattle. J. Anim. Sci. 69:433-442.

Hach. 1987. Feed Analysis Manual. Hach Co., Ames, IA.

Kartchner, R.J. 1980. Effects of protein and energy supplementation of cows grazing native winter range forage on intake and digestibility. $J$. Anim. Sci. 51:432-438.

Krysl, L. J., M. E. Branine, A. U. Cheema, M. A. Funk, and M. L. Galyean. 1989. Influence of soybean meal and sorghum grain supplementation on intake, digesta kinetics, ruminal fermentation, site and extent of digestion and microbial protein synthesis in beef steers grazing blue grama rangeland. J. Anim. Sci. 67:3040-3051.

NRC. 1984. Nutrient requirements of beef cattle. 6th Revised Ed. National Academy Press, Washington DC.

Sanson, D. W., D. C. Clanton, and I. G. Rush. 1990. Intake and digestion of low-quality meadow hay by steers and performance of cows on native range when fed protein supplements containing various levels of com. J. Anim. Sci. 68:595-603.

SAS. 1989. SAS users guide: Basics. SAS Institute, Cary, NC.

Ward, M.G., D.C. Adams, J.D. Wallace, M.L. Galyean, and B.W. Knapp. 1990a. Supplementation and monensin effects on digesta kinetics I. Cattle grazing summer range. J. Range Manage. 43:378-382.

Ward, M.G., D.C. Adams, J.D. Wallace, M.L. Galyean, and B.W. Knapp. 1990b. Supplementation and monensin effects on digesta kinetics II. Cattle grazing winter range. J. Range Manage. 43:383-386.

Williams, C. H., D. J. David, and O. lismaa. 1962. The determination of chromic oxide of faeces samples by atomic absorption spectrophotometry. J. Agr. Sci. 59:381-385. 